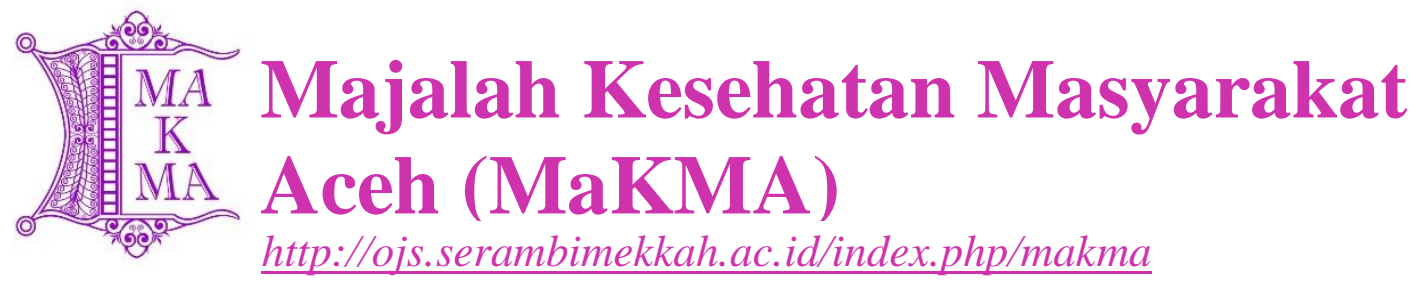

\title{
PEMERIKSAAN TELUR SOIL TRANSMITTED HELMINTHS PADA KOTORAN KUKU PEMULUNG DI TEMPAT PEMBUANGAN AKHIR (TPA) SAMPAH
}

\author{
Agus Widodo $^{1}{ }^{\bowtie}$ Kartika Ikawati $^{2}$ Listiani $^{3}$ \\ Akademi Analis Kesehatan 17 Agustus 1945 Semarang \\ ${ }^{凶}$ Alamat Korespondensi: Jalan Jendral Sudirman 350 Semarang / aguswede.mijen@ gmail.com / \\ 0811277110
}

\begin{abstract}
ABSTRAK
Kebiasaan buruk pemulung yang tidak mengindahkan pengelolaan sampah dan kebersihan diri mengakibatkan bakteri dan parasit khususnya Soil Transmitted Helminths dapat dengan mudah menginfeksi. Soil Transmitted Helminths terdiri dari: Ascaris lumbricoides, Necator americanus, Ancilostoma duodenale, Trichuris trichiura, dan Strongiloides stercoralis. Pemulung sangat rentan terinfeksi telur Soil Transmitted Helminths tersebut. Tujuan penelitian ini untuk mengetahui adanya infeksi Soil Transmitted Helmiths pada kotoran kuku pemulung di Tempat Pembuangan Akhir (TPA) Sampah Jatibarang Kecamatan Semarang Barat. Jenis penelitian ini adalah deskriptif dengan sampel sebanyak 67 orang yang diambil dengan teknik random sampling. Sebagai obyek penelitian adalah kuku pemulung yang diperiksa dengan metode Pengapungan $\mathrm{NaCl}$ jenuh. Prinsip dari metode ini yaitu mengapungkan parasit yang ada di kuku dengan pelarut yang berat jenisnya lebih tinggi dari berat jenis parasit. Dengan pelarut $\mathrm{NaCl}$ jenuh, maka parasit akan terapung. Berdasarkan pemeriksaan dari 64 sampel (37 perempuan dan 30 laki-laki) didapatkan hasil positif A.lumbricoides 7 orang (10,5 $\%)$, Cacing tambang $0(0 \%)$, T.trichiura 5 orang $(7,4 \%)$, dan S.stercoralis $0(0 \%)$. Pada kasus infeksi ganda didapatkan hasil 1 orang wanita $(2,7 \%)$ terkontamisasi A. Lumbricoides dan $T$. Trichiura, dan 1 orang laki-laki $(3,3 \%)$ terkontamisasi A. Lumbricoides dan T. Trichiura. Semarang
\end{abstract}

Kata Kunci : Kuku, Pemulung, Soil Transmitted Helminths.

Riwayat Artikel

Diterima : 19 Juli 2019 


\title{
EXAMINATION OF SOIL TRANSMITTED HELMINTHS EGG IN DIRTY NAILWATER NAILS IN WASTE FINAL DISPOSAL PLACES
}

\begin{abstract}
Bad habits of scavengers who do not heed waste management and personal hygiene result in bacteria and parasites, especially the Soil Transmitted Helminths, can easily infect. Soil Transmitted Helminths consist of: Ascaris lumbricoides, Necator americanus, Ancilostoma duodenale, Trichuris trichiura, and Stercoralis Strongiloides. Scavengers are very vulnerable to being infected with the eggs of Soil Transmitted Helminths. The purpose of this study was to determine the presence of Soil Transmitted Helmiths infection in scavenger nail feces in the Jatibarang Waste Disposal Site (TPA) in West Semarang District. This type of research is descriptive with a sample of 67 people taken by random sampling technique. As the research object, scavenger nails were examined by saturation of saturated $\mathrm{NaCl}$ method. The principle of this method is to float parasites in nails with solvents whose specific gravity is higher than the specific gravity of the parasite. With a saturated $\mathrm{NaCl}$ solvent, the parasite will float. Based on the examination of 64 samples ( 37 women and 30 men) there were positive results of A.lumbricoides 7 people (10.5\%), Hookworm $0(0 \%)$, T.trichiura 5 people (7.4\%), and S.stercoralis $0(0 \%)$. In the case of multiple infections, 1 woman $(2.7 \%)$ was contaminated with A. lumbricoides and T. trichiura, and 1 male (3.3\%) was contaminated with A. lumbricoides and T. Trichiura Semarang.
\end{abstract}

Keywords: Nails, Scavengers, Soil Transmitted Helminths. 


\section{PENDAHULUAN}

Sampah sebagai hasil sampingan dari berbagai aktivitas dalam kehidupan manusia maupun sebagai hasil dari proses alamiah, seringkali menimbulkan permasalahan di perkotaan. Semakin berkembang suatu kota akibat pertambahan jumlah penduduk serta peningkatan aktivitas hidupnya menyebabkan masalah yang ditimbulkan oleh sampah semakin besar dan kompleks. ${ }^{[1]}$

Sampah juga merupakan masalah yang tak pernah terselesaikan hingga saat ini, meskipun di negara maju telah menindak tegas orangorang yang suka membuang sampah sembarangan, namun belum juga membuat pembuang sampah sembarangan menjadi jera, apalagi di negara berkembang yang bahkan belum memiliki undang-undang yang jelas mengenai masalah ini. ${ }^{[2]}$

Akibat dari kebiasaan buruk tersebut, mengakibatkan parasit dan bakteri dari sampah tersebut dapat dengan mudah menyebarkan penyakit di masyarakat. Di negara kaya dan maju, banyak penyakit parasit dapat diberantas, sebaliknya di Negara miskin dan terbelakang memperlihatkan prevalensi yang lebih tinggi. Berdasarkan hasil penelitian Budiyono pada tahun 1996 di TPA Jatibarang Semarang, menunjukkan jumlah pemulung yang positif kecacingan cacing usus sebanyak $58,23 \%$ dari 79 responden yang diperiksa. Dari penelitiannya juga menunjukkan adanya hubungan bermakna antara tingkat kebersihan tangan, tingkat pemakaian alas kaki, tingkat kebersihan kuku, tingkat pemakaian jamban serta tingkat kebersihan kaki dengan infeksi cacing usus pada pemulung. ${ }^{[3]}$

Demikian juga hasil penelitian pada tahun 2005, diketahui sebanyak
47,5\% pemulung di TPS Jatibarang mengalami kecacingan dengan jenis infeksi tunggal dan tidak ada infeksi ganda. Tahun 2010 hasil penelitian pada pemulung di Tempat Pembuangan Akhir Kalongan ungaran Kabupaten Semarang menunjukkan prevalensi kecacingan sebesar 21,4\%. Hasil survei Departemen Kesehatan Republik Indonesia di beberapa provinsi di Indonesia menunjukkan prevalensi kecacingan untuk semua umur di Indonesia berkisar antara 40\%-60\%. Tingginya prevalensi ini disebabkan oleh iklim tropis dan kelembaban udara tinggi di Indonesia, yang merupakan lingkungan yang baik untuk perkembangan cacing, serta kondisi higiene dan sanitasi yang buruk. ${ }^{[4]}$

Dengan demikian penyakit parasit sangat erat hubungannya rendahnya pengetahuan suatu masyarakat. Hal ini terlihat di kawasan sekitar TPA Jatibarang. Seperti diketahui TPA Jatibarang merupakan tempat pembuangan akhir di Semarang yang lokasinya dekat dengan pemukiman penduduk. Sebagian besar penduduk, yang bekerja sebagai pemulung, setiap hari memilah sampah berhubungan langsung dengan sampah dan sangat rentan untuk terinfeksi. Pada penelitian sebelumnya ${ }^{[5]}$ didapatkan data sebanyak 150 pemulung tinggal di area sekitar TPA dengan satu sumber air bersih dan satu jamban sehat. Hasil observasi awal mendapatkan lebih 50\% pemulung berperilaku hidup tidak sehat. Pemulung biasa buang air besar di kebun dan sungai. Pemulung juga tidak biasa menggunakan sarung tangan saat bekerja, kuku kotor dan jarang menggunakan sabun yang mengandung antiseptik saat mencuci tangan dan setelah Buang Air Besar (BAB) .

Dengan penularannya melalui kuku tangan yang tidak menggunakan APD (Alat Pelindung Diri), pada saat 
memilah sampah, serta membiarkan kuku kotor dan panjang sehingga lebih mudah terinfeksi telur Soil Transmitted Helminths $\mathrm{STH}^{[6]}$. Oleh karena itu, kuku yang kotor akan membawa bibit penyakit, diantaranya diare, kecacingan, dan penyakit-penyakit lainnya yang ditimbulkan oleh kuman, jamur dan parasit

Soil Transmitted Helminths

(STH) merupakan nematode usus yang penularannya melalui tanah, adapun spesiesnya yaitu Ascaris lumbricoides (A. lumbricoides), Trichuris trichiura (T. trichiura), Cacing tambang Necator americanus (N. americanus), Ancylostoma duodenale (A. duodenale), dan Strongiloides strecoralis (S.

\section{METODE}

Penelitian yang dilakukan di Laboratorium Parasitologi Akademi Analis Kesehatan 17 Agustus 1945 Semarang ini bersifat deskriptif, dan dilaksanakan selama 6 bulan (November 2018 s/d Maret 2019). Populasi pada penelitian ini adalah pemulung di daerah Jatibarang Kecamatan Semarang Barat sebanyak 200 orang. Besar sampel minimal ditentukan menurut rumus slovin sebanyak 67 pemulung dengan teknik random sampling. Objek penelitian adalah kotoran kuku pemulung di TPA Sampah Jatibarang Kecamatan Semarang Barat dengan menggunakan Metode Pengapungan $\mathrm{NaCl}$ Jenuh. Obyek pemeriksaan yang telah diperoleh kemudian diobservasi atau diamati secara langsung, kemudian diperiksa di Laboratorium Parasitologi Akademi Analis Kesehatan 17 Agustus 1945 Semarang dengan menggunakan Metode Pengapungan $\mathrm{NaCl}$ Jenuh.

Pengambilan sampel dilakukan dengan cara memotong kuku yang kotor pada pemulung, kemudian ditampung dalam wadah yang bersih dan ditutup rapat. Masing-masing Sampel diberi
Stercoralis ). ${ }^{[7]}$ Infeksi cacing juga terjadi dengan tertelannya telur yang berisi embrio dengan perantara melalui kuku tangan, makanan atau minuman yang secara langsung terkena kontaminasi tanah atau secara tidak langsung melalui binatang maupun debu. ${ }^{[8]}$

Untuk mengetahui adanya infeksi Soil Transmitted Helmiths (STH) pada kotoran kuku pemulung di Tempat Pembuangan Akhir (TPA) sampah di Daerah Jatibarang Kecamatan Semarang Barat, maka perlu dilakukan pemeriksaan dengan Metode Pengapungan $\mathrm{NaCl}$ Jenuh.

label nama, umur dan jenis kelamin, kemudian dibawa ke Laboratorium Parasitologi. Setelah sampel diperoleh dilakukan pemeriksaan dengan menggunakan metode Pengapungan $\mathrm{NaCl}$ Jenuh. Prinsip kerjanya adalah mengapungkan parasit yang ada di kuku dengan pelarut yang berat jenisnya lebih tinggi dari berat jenis parasit dengan pelarut $\mathrm{NaCl}$ jenuh, maka parasit akan terapung, dan diamati di bawah mikroskop Prosedur kerjanya adalah mengambil sampel dengan memotong kuku tangan, kemudian dimasukkan ke dalam wadah yang sebelumnya diisi $\mathrm{NaCl}$ jenuh, diaduk sampai homogen, $\mathrm{NaCl}$ jenuh yang berisi kotoran kuku disaring dengan kain kasa dan dimasukkan ke dalam tabung reaksi sampai penuh, kemudian ditutup dengan deck glass dan ditunggu \pm 60 menit. Selanjutnya deck glass diletakkan pada objek glass dan dilihat di bawah mikroskop dengan perbesaran total $100 \mathrm{X}$ dan $400 \mathrm{X}$. Data pemeriksaan yang telah terkumpul dibuat presentase kontaminasi telur STH dengan rumus : 
$\underline{\Sigma X} \times 100 \%$

$\mathrm{N}$

$\mathrm{X}=$ jumlah positif atau negat if

$\mathrm{N}=$ jumlah keseluruhan sampel

Alat yang digunakan pada penelitian ini adalah 1) Tabung reaksi, 2) Rak tabung reaksi, 3) Kaca benda (objek glass), 4) Kaca penutup (deck

HASIL

Pemeriksaan telur Soil Transmitted Helminths pada kotoran kuku pemulung di Tempat Pembuangan Akhir (TPA) sampah di Daerah Jatibarang Kecamatan Semarang Barat dengan metode pengapungan $\mathrm{NaCl}$ jenuh yang berjumlah 67 (37 Perempuan, 30 Laki-laki) sampel diperoleh hasil positif terkontaminasi Soil Transmitted Helminths sebanyak 12 sampel atau $17,9 \%$ dari jumlah sampel. Dari 17,9\% yang positif terkontaminasi tersebut ditemukan 2 spesies yaitu A. Lumbricoides dan T. Trichiura, dengan penyebaran 7 sampel atau $10,5 \%$ positif terkontaminasi A. Lumbricoides dan 5 sampel atau $7,4 \%$ positif terkontaminasi T. Trichiura [Tabel.1]. glass), 5) Corong, 6) Pipet tetes, 7) Batang pengaduk, 8) Mikroskop, sedangkan bahan yang digunakan: 1) kotoran kuku tangan, 2) $\mathrm{NaCl}$ jenuh. Analisis data dilakukan dengan cara deskriptif berdasarkan jenis cacing STH dan jenis kelamin pemulung.

Penyebaran berdasarkan jenis kelamin didapatkan hasil 3 perempuan atau $8,1 \%$ positif terkontaminasi A. Lumbricoides dan 2 perempuan atau $5,4 \%$ positif terkontaminasi T. Trichiura. Sementara untuk laki-laki yang positif terkontaminasi A. Lumbricoides sebanyak 4 orang atau $13,3 \%$ dan yang positif terkontaminasi T. Trichiura sebanyak 3 orang atau $10 \%$ [Tabel.2].

Pada kasus infeksi ganda (berdasarkan jenis kelamin) dalam penelitian ini didapatkan hasil 1 orang wanita $(2,7 \%)$ positif terkontamisasi A. Lumbricoides dan T. Trichiura, sementara pada laki-laki 1 orang $(3,3 \%)$ positif terkontamisasi A. Lumbricoides dan T. Trichiura [Tabel.3]. 


\section{PEMBAHASAN}

Hasil penelitian ini selaras dengan penelitian Budiyono pada tahun 1996 di TPA Jatibarang Semarang, menunjukkan jumlah pemulung yang positif kecacingan Nematoda usus sebanyak 58,23\% dari 79 responden yang diperiksa. ${ }^{[3]}$ Demikian juga hasil penelitian pada tahun 2016 oleh Kartika Ikawati dari 120 pemulung yang tinggal di area bawah TPA didapatkan 57 orang atau $47,5 \%$ positif kecacingan dan 63 orang atau $52,5 \%$ tidak kecacingan. ${ }^{[4]}$

Adanya infeksi yang di sebabkan oleh Ascaris lumbricoides atau biasa disebut dengan cacing gelang dan $T$. Trichiura atau biasa disebut cacing cambuk ini dipe ngaruhi oleh beberapa faktor. Menurut WHO lebih dari $10 \%$ populasi dunia terinfeksi cacing, dan paling banyak disebabkan oleh cacing gelang. ${ }^{[9]}$ Pravalensi A. lumbricoides di Indonesia sangat tinggi $70-90 \%$, telur A. lumbricoides sangat baik hidup di tanah. Kelembaban tinggi dengan suhu $25-30^{\circ} \mathrm{C}^{[7]}$

Dari hasil observasi dan wawancara pada pemulung di TPA Jatibarang diketahui bahwa pemulung yang terkontaminasi Ascaris lumbricoides dan T. Trichiura :

1. Tidak biasa menggunakan sarung tangan saat bekerja. Seperti halnya penelitian dari Kartika Ikawati (2016) di mana mendapatkan hasil pemulung di TPA Jatibarang $61,7 \%$ tidak menggunakan sarung tangan sedangkan pemulung yang biasa memakai sarung tangan hanya $38.3 \% .^{[4]}$

2. Tidak Rutin Memotong Kuku Pemulung di TPA Jatibarang sebagian besar $(73 \%)$ tidak memotong kuku satu kali dalam satu minggu. Hanya $27 \%$ yang biasa potong kuku satu kali dalam satu minggu. ${ }^{[4]}$ Kuku yang panjang dan tidak terawat menjadi sarang berkumpulnya mikroorganisma seperti bakteri dan telur cacing. Mikroorganisma tersebut bisa masuk ke mulut lewat makanan dan minuman yang dipegang oleh tangan yang kotor. Hal ini selaras dengan penelitian dari Dly Zukhriadi, yang mendapatkan hasil terdapat hubungan bermakna antara kebiasaan memotong kuku dengan kecacingan. ${ }^{[10]}$ Kuku manusia dalam waktu satu minggu rata-rata hanya bertambah panjang $0.5 \mathrm{~mm}$. Kemungkinan pertambahan panjang $0.5 \mathrm{~mm}$ belum menyebabkan bersarangnya kuman yang banyak. ${ }^{[11]}$

3. Tidak Cuci Tangan Pakai Sabun Antiseptik Sebelum Makan

Sebesar 52\% pemulung tidak biasa cuci tangan pakai sabun yang mengandung antiseptik sebelum makan. Kebiasaan tidak mencuci tangan pakai sabun yang mengandung antiseptik sebelum makan mempunyai hubungan dan merupakan faktor risiko tertingi kedua terhadap kecacingan. Hasil ini sama seperti penelitian Dly Zukhriadi yang dilakukan pada anak Sekolah Dasar Kota Sibolga pada tahun 2008. ${ }^{[10]}$ Dari hasil observasi diketahui pemulung TPA Jatibarang tidak mengetahui sabun yang mengandung antiseptik. Pemulung juga tidak menyadari jika sabun yang dibeli mengandung antiseptik. Mencuci tangan dengan menggunakan air bersih dan sabun yang mengandung antiseptik dapat menghilangkan dan membunuh kuman lebih. Pada umumnya antiseptik yang terdapat dalam sabun adalah triclosan dan triclocarban atau benzyl alkohol. Menurut Rahardjo (2008) zat aktif tersebut setara dengan fenol $2 \%$. Fenol dengan konsentrasi $(0.5-2 \%)$ 
dapat digunakan sebagai antiseptik untuk menghambat aktivitas bakteri, jamur dan parasit. Fenol bekerja dengan cara mendenaturasi protein sel dan merusak membran sel. $^{[4]}$

4. Kecukupan Air bersih Tidak Memadai.

Diketahui sebanyak 91 atau $76 \%$ pemulung TPA Jatibarang kurang akses air bersih. Hanya 29 orang (24\%) diantara mereka yang dapat mengusahakan kecukupan air bersih. Pemulung TPA Jatibarang sering menggunakan air sungai yang terkontaminasi faeces untuk mandi dan mencuci baju. Secara substansial seorang yang menggunakan air sungai yang terkontaminasi faeces meningkatkan resiko terkena kecacingan. Dari hasil observasi diketahui meskipun pemulung sering menggunakan air sungai, namun untuk keperluan memasak, makan dan minum tetap menggunakan air sumur yang dimasak. Kuman seperti bakteri dan parasit akan mati lewat pemanasan suhu tinggi ${ }^{[12]}$.

Tidak ditemukannya Strogiloides stercoralis atau biasa disebut cacing kremi, karena cacing kremi lebih banyak ditemukan di daerah dingin dan lebih sering menyerang pada anak. ${ }^{[13]}$ Sedangkan TPA Jatibarang bukan daerah dingin, dan pemulung sebagian besar dewasa. Cacing Strogiloides Stercoralis tidak ditemukan pada penelitian ini. Sementara untuk Prevalensi cacing tambang (Hookworm) pada pemulung di TPA Jatibarang didapatkan 29,8\% atau lebih sedikit dari pada Ascaris Lumbricoides. Hal ini sejalan dengan sumber yang menyebutkan bahwa prevalensi cacing tambang dapat mencapai $60-70 \%$ di daerah perkebunan dan pertambangan. ${ }^{[14]}$ Sedangkan tempat pembuangan akhir Sampah Jatibarang bukan daerah perkebunan atau pertambangan.

\section{KESIMPULAN DAN SARAN}

Berdasarkan hasil pemeriksaan telur STH (Soil Transmitted Helminths) pada kotoran kuku pemulung di Tempat Pembuangan Akhir (TPA) Sampah di Daerah Jatibarang Kecamatan Semarang Barat dengan metode pengapungan $\mathrm{NaCl}$ jenuh didapatkan hasil adanya kontaminasi Soil Transmitted Helminths sebanyak 12 sampel atau $17,9 \%$. Jenis spesies yang ditemukan yaitu A. Lumbricoides dan T. Trichiura, dengan penyebaran 7 sampel atau $10,5 \%$ positif terkontaminasi A. Lumbricoides dan 5 sampel atau $7,4 \%$ positif terkontaminasi T. Trichiura.

Adanya infeksi yang disebabkan oleh Ascaris Lumbricoides atau biasa disebut dengan cacing gelang dan T. Trichiura atau biasa disebut cacing cambuk ini dipe ngaruhi oleh beberapa faktor, antara lain: Tidak memakai sarung tangan, tidak rutin memotong kuku, tidak cuci tangan pakai sabun antiseptik sebelum makan, dan kecukupan air bersih tidak memadai.

Dari hasil penelitian yang dilakukan pada kotoran kuku pemulung di Tempat Pembuangan Akhir (TPA) Sampah di Daerah Jatibarang Kecamatan Semarang Barat dengan metode pengapungan $\mathrm{NaCl}$ jenuh, untuk menghindari dan mencegah adanya kontaminasi Soil Transmitted Helminths, kami sebagai penulis memberikan beberapa saran:

Memelihara kuku dengan baik seperti memotong kuku dan membersihkan kuku setiap seminggu sekali. Mencuci tangan manggunakan sabun antiseptik dan air mengalir. Menjaga kebersihan lingkungan dan menggunakan sarung tangan atau alat pelindung diri pada saat bekerja. 
DAFTAR PUSTAKA

1. Slamet, J.S. Kesehatan Lingkungan. Gadjah Mada University Press. Yogyakarta: (2004)

2. Soedarto. Helmintologi kedokteran. EGC, Jakarta : (1992)

3. Fauziah, "Faktor - Faktor Yang Berhubungan Dengan Kejadian 9. Penyakit Ascariasis, Trichuriasis dan Anchylostomiasis Pada Pemulung di Tempat Pembuangan Akhir (TPA) di Antang". Skripsi. FKM Unhas, Makassar: ( 2006)

4. Ikawati, K., Rahadi, W., Ariani, L., \& Adi, M. S. (2016). Hubungan perilaku hidup bersih dan sanitasi lingkungan terhadap kecacingan pada pemulung. Jurnal Keperawatan dan Kesehatan Masyarakat Cendekia Utama, 5(1).

5. Depkes Pengendalian 2006).Diunduh

RI. (Pedoman Kecacingan. http://www.depkes.go.id

6. Siswanto, Hadi. Pendidikan Kesehatan Anak UsiaDini. Pustaka Rihana, Yogyakarta: (2010).
7. Sutanto, Inge, dkk . Parasitologi Kedokteran, Fakultas Kedokteran Universitas Indonesia, Jakarta: (2015)

8. Anuar, T.S, F. M, \& Moktar, N. Faktor Resiko Kecacingan Terkait dengan Tanah, Int J Sci Rep.4 : Malaysia: (2014).

9. Cromton, DW. Ascaris and Ascariasis parasitology, (2001).48, pp. 285-375. https://www.alodokter.com/ascariasis

10. Dly Zukhriadi,R,R.. Hubungan Personal Higiene Perorangan Siswa Dengan Infeksi Kecacingan Anak SD Negeri Di Kecamatan Sibolga Kota. Pasca Sarjana USU. Medan: (2008)

11. Mubarak Wahid I, Ilmu Kesehatan Masyarakat Teori dan Aplikasi, Salemba Medika, Jakarta : (2009).

12. Notoatmodjo Soekidjo,.Pengantar Pendidikan dan Ilmu Kesehatan Masyarakat, Andi Offset, Yogyakarta : (2007)

13. Brown Harold W. Dasar Parasitologi Klinik, Ed ke-III, PT Gramedia, Jakarta $\therefore$ (2011).

14. Soedarto,Buku Ajar Parasitologi, Sagung Seto, Jakarta : (2011). 


\section{LAMPIRAN}

Tabel [1]. Distribusi Kontaminasi STH pada Pemulung di TPA Jatibarang

\begin{tabular}{clcccccc}
\hline \multirow{2}{*}{ No } & \multirow{2}{*}{ Jenis Cacing } & \multicolumn{2}{c}{ Positif } & \multicolumn{2}{c}{ Negatif } & \multicolumn{2}{c}{ total } \\
\cline { 3 - 8 } 1 & $\boldsymbol{\Sigma}$ & $\boldsymbol{\%}$ & $\boldsymbol{\Sigma}$ & $\%$ & $\boldsymbol{\Sigma}$ & $\%$ \\
\hline & A. lumbricoides & 7 & 10,5 & 60 & 89,5 & 67 & 100 \\
2 & Cacing tambang & 0 & 0 & 67 & 100 & 67 & 100 \\
3 & T. trichiura & 5 & 7,4 & 62 & 92,6 & 67 & 100 \\
4 & S. stercoralis & 0 & 0 & 67 & 100 & 67 & 100 \\
\hline
\end{tabular}

Tabel [2]. Distribusi Kontaminasi STH pada pemulung di TPA Jatibarang Berdasarkan Jenis Kelamin

\begin{tabular}{cllcccccc}
\hline \multirow{2}{*}{ No } & \multirow{2}{*}{$\begin{array}{c}\text { Jenis } \\
\text { Kelamin }\end{array}$} & \multirow{2}{*}{ Spesies } & \multicolumn{2}{c}{ Positif } & \multicolumn{2}{c}{ Negatif } & \multicolumn{3}{c}{$\begin{array}{c}\text { Jumlah } \\
\text { Total }\end{array}$} \\
\cline { 4 - 9 } & & $\Sigma$ & $\%$ & $\Sigma$ & $\%$ & $\Sigma$ & $\%$ \\
\hline \multirow{2}{*}{ 1. } & Perempuan & \multirow{2}{*}{ A. lumbricoides } & 3 & 8,1 & 34 & 91,9 & 37 & 100 \\
& Laki-laki & 4 & 13,3 & 26 & 86,7 & 30 & 100 \\
2. & Perempuan & Cacing & 0 & 0 & 37 & 100 & 37 & 100 \\
& Laki-laki & tambang & 0 & 0 & 30 & 100 & 30 & 100 \\
3. & Perempuan & T. trichiura & 2 & 5,4 & 35 & 94,6 & 37 & 100 \\
& Laki-laki & & 3 & 10 & 27 & 90 & 30 & 100 \\
4. & Perempuan & \multirow{2}{*}{ S. stercoralis } & 0 & 0 & 37 & 100 & 37 & 100 \\
& Laki-laki & & 0 & 0 & 30 & 100 & 30 & 100 \\
& Jumlah Total & & 12 & 17,9 & 55 & 82,1 & 67 & 100 \\
\hline & Sampel & & & & & & &
\end{tabular}

Tabel [3]. Distribusi Kontaminasi Ganda Soil Transmitted Helminths

\begin{tabular}{cllcc}
\hline No & Jenis kelamin & Infeksi Ganda & Jumlah & \% \\
\hline 1 & Perempuan & A. L dan TT & 1 & 2,7 \\
2 & Laki-laki & A. L dan TT & 1 & 3,3 \\
\hline
\end{tabular}

